\begin{abstract}
MINUTES OF THE MEETINGS OF THE JUDICIAL COMMISSION OF THE INTERNAT IONAL COMMITTEE ON BACTERIOLOGICAL NOMENCLATURE HELD AT STOCKHOLM IN CONNECTION WITH THE VII INTERNATIONAL CONGRESS FOR MICROBIOLOGY AUGUST 4-9, 1958
\end{abstract}

The first meeting of the Judicial Commission of the International Committee on Bacteriological Nomenclature was held on July 31, 1958, at the Karolinska Institute, Stockholm, Sweden. Those present were R.E. Buchanan (Chairman), C.H. Andrewes, A.A. Miles, E.G.D. Murray, J. Ramsbottom, P.Schaeffer, A. Sordelli, and W.A. Clark and S.T. Cowan, Secretaries.

Minute 1. The agenda prepared by the Secretary were approved.

Minute 2. Apologies for absence were received from A. Lwoff and C.B. van Niel and their alternates, P. Schaeffer and M. P. Starr, respectively, accepted.

Minute 3. Minutes of the last meeting, published in the International Bulletin of Bacteriological Nomenclature and Taxonomy, 1953, 3:141-154, were taken as read. No corrections were received, and the minutes were approved.

Minute 4. Matters arising from the minutes. The ann otated Bacteriological Code, authorized at the Rome Congress, was published in June 1958. A minor omission from Table IV, viz. reference to Opinion 4 (revised), the rejection of the generic name Bacterium, was noted, and it was agreed that, if practicable, correction slips should be inserted in unsold copies, and that known purchasers would be notified.

It was agreed that discussion relative to any proposed emendations to the revised International Code of Nomenclature of the Bacteria and Viruses (1958) be deferred until after the close of the VII International Microbiological Congress (1958) and considered in preparation for and at the VI II Congress. The Judicial Commission under the Provisions of the Code will act on nomenclatural problems that arise through OPINIONS issued, shall consider all proposals for emendation (Page 135) 
Page 136

I N T ERNATIONAL B ULLE T I N

of the Code and prepare recommendations for consideration by the International Committee at its meeting in connection with the VIII Congress.

Minute 5. Joint Permanent Secretary representing normedical bacteriology. Prof. T. Wikën resigned in April 1957 as Joint Secretary, and W.A. Clark, approved by postal ballot of Commissioners, had acted in his place since October 1957. Dr. Clark's appointment as Joint Permanent Secretary representing nonmedical bacteriology was recommended to the Inte mational Committee on Bacteriologica I Nomenclature.

Minute 6. Relation of Nomenc lature Committee and Commiss ion to the International Union of Biological Sciences (IUBS).

(a) In the past the Nomenclature Committee received grants-in-aid directly from IUBS. These grants will in future be sought by application through the Executive Committee of the International Association of Microbiological Societies (IAMS).

(b) International Union of Biological Sciences at the meeting in July 1958 authorized an ad hoc committee to compare and try to correlate certain differences in teminology between the nomenclatural codes in bacteriology, botany, and zoology, each discipline to appoint two members to the IUBS Committee. It was agreed to recommend to the Exec utive Committee of IAMS the appointment of R.E. Buchanan and J. Ramsbottom to the ad hoc committee authorized by the Inte rnational Union of Biological Sciences.

(c) The allocation of UNESCO funds received from IUBS for the support of culture collections was discussed, and recommendations were made to the IAMS Executive Committee to be forwarded by the Nomenclature Committee. These included the authorization of a subcommittee of the Judicial Commission to advise on the allocation of funds.

(d) The Judicial Commission formulated and adopted a resolution on "Allocation of Subventions to Culture Collections of Microorganisms" which was recommended to the International Committee for transmission to the Executive Committee for transmission to the Executive Committee. The text of this resolution is given on page 185 of this BULLETIN. 
Minute 7. Relation of the Nomenclature Committee to the Executive Committee of IAMS. The Nomenclature Committee was founded in 1930 and is the only body within IAMS which has Permanent Secretaries to ensure continuity. It was agreed that a representative of the Nomenclature Committee could serve a useful purpose on the Executive Committee of the Ifiss. It was agreed to recommend to the International Committee on Bacteriological Nomenclature that this Committee propose to the Executive Committee of the International Association of Microbiological Soieties that a representative of the International Committee on Bacteriological Nomenclature be added to its membership. In the event that the International Committee accepts this recommendation, it is further suggested that E.G.D. Murray be nominated to this post.

The Judicial Commission agreed to recommend to the International Committee on Bacteriological Nomenclature that this Committee propose to the Executive Committee of the International Association of Microbiological Societies that the Executive Committee authorize the Judicial Commission to appoint a Subcommittee to advise the Executive Committee on the allocation of funds provided by the International Union of Biological Sciences to Culture Collections.

Minute 8. Report of the Editorial Board. The Report of the Editorial Board was submitted and approved. A change in the format and printing of the BULLETIN was discussed and the Editorial Board was authorized to find out approximate costs and facilities and to report to the Commission.

Minute 9. Official Opinions had been requested on various subjects and were considered.

Opinion 16. Conservation of the generic name Chromobacterium Bergonzini 1881 and designatioh of the type species and of a neotype culture.

1. The generic name Chromobacterium* Bergonzini 1879 is rejected and placeu $i$ in the list of nomina generum rejicienda.

\footnotetext{
*Originally named Cromobacterium, later emended to conform to recommendations in the Code, Appendix A.
} 
2. The generic name Chromobacterium Bergonzini 1881 is conserved and placed in the list of nomina generum conservàndi.

3. The type species of the genus Chromobacterium Bergonzini 1881 is Chromobacterium violaceum Bergonzini 1881.

4. A neotype strain of Chromobacterium violaceum Bergonzini 1881 is designated and has been deposited in the American Type Culture Collection, Washington, D.C. (12472) and in the National Collection of Iype Cultures, London (9757).

Opinion 17. Conservation of the generic name
Staphylococcus Rosenbach, designation of Staphylo-
coccus aureus Rosenbach as the nomenclatural type
of the genus Staphylococcus Rosenbach, and the
designation of a neotype culture of Staphylococcus
aureus Rosenbach.

1. The generic name Staphylococcus Rosenbach 1884 is conserved and placed in the list of nomina generum conservanda.

2. Staphylococcus aureus Rosenbach 1884 is recognized as the nomenclatural type species of the genus Staphylococcus Rosenbach 1884 .

3. The strain labeled 8532 in the National Collection of Type Cultures, London, is designated as the neotype strain of the species Staphylococcus aureus Rosenbach 1884.

$$
\begin{aligned}
& \text { Opinion 18. Legitimacy of the epithets typhosa } \\
& \text { and typhi when applied to the organism which } \\
& \text { causes enteric fever. * }
\end{aligned}
$$

The specific epithet typhosa in the name of the species Salmonella typhosa (Zopf) White has priority over the spec ific epithet typhi in the species name Salmonella typhi (Schroeter) Warren and Scott, its basonym being Bacterium typhosum Zopf 1884 .

\footnotetext{
*The International Committee on Bacteriological Nomenclature requested that a survey of current usage be made before final formulation and issuance of this OPINION.
} 
Cpinion 19. Conservation of the generic name Fickettsia da Rocha-Lima and of the species name Pickettsia prowazekii.

1. The generic name Rickettsia da Rocha-Lima is conserved against Stricheria Stempell, and the specific epithet prowazekii in the species name Rickettsia prowazekii da Rocha-Lima is conserved against the specific epithet jurgensi first used in the species name Stricheria jurgens i Stempell.

2. The generic name Stricheria Stempell and the species name Stricheria jurgensi Stempell are rejected and placed in the appropriate lists of rejected names.

\section{Opinion 20. Status of new generic names of bacteria published without names of included species.}

1. Name of a hypothetical genus. A hypothetical genus is one in which no species is described, named, or cited; the existence of the genus is predicated upon the future discovery and description of species as yet unknown. A name applied to a hypothetical genus is not validly published and may be placed in the list of nomina rejicienda.

2. Name of a "temporary" genus. A generic name proposed for a genus whose sole function is to serve as the temporary generic haven for insufficiently described species, which species may be allocated later to an appropriate genus or genera, is to be regarded as not validly published. Such a name may be placed in the list of nomina rejicienda.

3. Name of a new genus with a described species which is neither named nor identified with a previously named species. A new generic name published in a combined description of a genus and species, without the species being named, without citation of a previously and effectively published description of the species, and without subsequent acceptance of the generic name and naming of the species by a later author, should be regarded as not validly published. Such a generic name may be placed in the list of nomina rejicienda. 
However, if a later author has recognized the generic name and has used it with a specific epithet in naming the species described by the first author, particularly if there has been later general acceptance of the name, there may be validation of the generic name as proposed by its author, with the name of the species ascribed to the later a uthor who gave it. Proposals for such validations of names should be made to the Judicial Commission for a ppropriate action.

4. Name of a new genus proposed to include one or more described and named species, but without simultaneous publication of the binary combination of generic name and specific epithet. A published generic name applied to a new genus in which the generic name is not used with a spec if ic epithet in naming any species, but in which there is citation of a previously and effectively published description of a species under another name, is to be regarded as validly published and the consequent combinationes novae ascribed likewise to the author of the generic name.

\section{Opinion 21. Status of the generic name \\ Selenomonas von Prowazek.}

1. The generic name Selenomonas von Prowazek 1913 was validly published with an accompanying description of the gerus.

2. The species Spirillum sputigenum Flügge is characterized and adequate references to description given: It was definitely assigned to the genus.

3. Selenomonas sputigena (Flügge) von Prowazek (basonym Spirillum sputigenum Flügge) is the type species of Selencmonas.

4. The generic name Selenomonas von Prowazek is placed in the list of nomina generum conservanda. 


\section{Opinion 22. The status of the generic name Asterococcus and conservation of the generic ridme Mycoplasmà.}

1. The generic name Asterococcus Borrel, Dujardin-Beaumetz, Jeantet and Jouan 1910 is a later homonym of Asterococcus Scherffel 1908, and hence illegitimate.

2. The generic name Mycoplasma Nowak 1929 is placed in the list of bacterial nomina generum conservanda as the first legitimate generic name proposed to replace Asterococus. The type species is Mycoplasma mycoides as determined by the basonym Asterococcus mycoides Borrel et al.

\section{Opinion 23. Status of the generic names Nitromonas, Nitrosomonas, Nitrosococcus, and Nitrobacter.}

1. The generic name Nitromonas Winogradsky 1890 is placed in the list of nomina generum rejicienda.

2. The generic name Nitromonas Orla-Jensen 1909 is a later homonym of Nitromonas Winogradsky and a later synonym of Nitrobacter Winogradsky. It is placed in the list of nomina generum rejicienda.

3. The generic name Nitrosomonas Winogradsky 1892 is placed in the list of nomina generum conservanda with Nitros amonas europaea Winogradsky as the nomenclatural type species.

4. The generic name Nitrosococcus Winogradsky 1892 is placed in the list of nomina generum conservanda, with the species described by Winogradsky and later named Nitrosococcus nitrosus (Migula) Buchanan as the nomenclatural type.

5. The generic name Nitrobacter Winogradsky 1892 is placed in the list of nomina generum conservanda, with the spec ies described by inogradsky and later named Nitrobacter winogradskyi winslow et a $\underline{1}$. as the nomenclatural type. 


\section{Opinion 24. Rejection of the generic name Arthrobacter Fischer 1895 and conservation of the generic name Arthrobacter Conn and Dimmick 1947.}

1. The name Arthrobacter Fischer 1895 proposed as the name of a hypothetical genus of bacteria was not validly published and has no standing in nomenclature.

2. The generic name Arthrobacter Conn and Dimmick 1947 wàs validly published as a nomen novum. It is neither an emendation of Arthrobacter Fischer 1895 nor a later homonym.

\section{Opinion 25. (Draft Proposal) Status of the generic name Chlamydozoon von Prowazek 1908}

Draft proposal 25 relative to the status of the generic name Chlamydozoon von Prowazek was considered, but no action taken pending further study.

\section{MEETING OF THE JUDICIAL COMMISSION, AUGUST 5, 1958}

Present were R.E. Buchanan (Chairman), C.H. Andrewes, A.A. Miles, E.G.D. Murray, J. Ramsbottom, P. Schaeffer, M.P. Starr (alternate for C.B. van Niel), and W.A. Clark and S.T. Cowan, Secretaries.

Minute 10. Reference back of Opinion 18. Opinion 18 had baen referred back to the Commission by the Nomenclature Committee for reconsideration. Action was deferred to give the Chairman time to prepare a statement for postal circulation to Commissioners.

Minute 11. International Bulletin. The Nomenclature Committee does not at this time desire a change of printing of the International Bulletin of Bacteriological Nomenclature and Taxonomy. The Commission maintained its opinion that the Editorial Board should find out the cost of printing the Pulletin in a new format. 
Minute 12 . New Subcommittees on Iaxonomy. The Chai man reported that a group of workers interested in the actinomycetes was meeting at the same time as this Congress. Also a nother group was considering the taxonomy of the azotobacters and it was likely that both groups would apply for recognition as taxonomic subcommittees of the International Committee on Bacteriological Nomenclature.

Minute 13. Proposed Symposium on Microbial Taxonomy. The secretaries were instructed to make a formal request through the International Committee on Bacteriological Nomenclature to the Executive Committee of the IAMS to seek a grant-in-a id from the International Union of Biological Sciences for holding of a symposium on microbial taxonomy and nomenclature at the next International Congress.

$$
\begin{aligned}
& \text { S. T. Cowan } \\
& \text { W. A. Clark }
\end{aligned}
$$

Joint Permanent Secretaries 
